Journal of Zhejiang University SCIENCE

ISSN 1009-3095

http://www.zju.edu.cn/jzus

E-mail: jzus@zju.edu.cn

\title{
The impact of $\mathrm{NiO}$ on microstructure and electrical property of solid oxide fuel cell anode
}

\author{
LI Yan (李 彦) ${ }^{1}$, LUO Zhong-yang (骆仲泱) ${ }^{\dagger+1}$, YU Chun-jiang (余春江) ${ }^{1}$, \\ LUO Dan (罗 丹 $)^{1}$, XU Zhu-an (许祝安 $)^{2}$, CEN Ke-fa (岑可法) ${ }^{1}$ \\ ( ${ }^{I}$ Institute for Thermal Power Engineering, Clean Energy and Environment Engineering Key Laboratory of \\ Ministry of Education, Zhejiang University, Hangzhou 310027, China) \\ ( ${ }^{2}$ Department of Physics, Zhejiang University, Hangzhou 310027, China) \\ †E-mail: zyluo@cmee.zju.edu.cn \\ Received July 14, 2005; revision accepted Sept. 2, 2005
}

\begin{abstract}
Ni}-\mathrm{Ce}_{0.8} \mathrm{Sm}_{0.2} \mathrm{O}_{1.9}$ (Ni-SDC) cermet was selected as anode material for reduced temperature $\left(800^{\circ} \mathrm{C}\right)$ solid oxide fuel cells in this study. The influence of $\mathrm{NiO}$ powder fabrication methods for Ni-SDC cermets on the electrode performance was investigated so that the result obtained can be applied to make high-quality anode. Three kinds of NiO powder were synthesized with a fourth kind being available in the market. Four types of anode precursors were fabricated with these NiO powders and $\mathrm{Ce}_{0.8} \mathrm{Sm}_{0.2} \mathrm{O}_{1.9}$ (SDC), and then were reduced to anode wafers for sequencing measurement. The electrical conductivity of the anodes was measured and the effect of microstructure was investigated. It was found that the anode electrical conductivity depends strongly on the $\mathrm{NiO}$ powder morphologies, microstructure of the cermet anode and particle sizes, which are decided by $\mathrm{NiO}$ powder preparation technique. The highest electrical conductivity is obtained for anode cermets with $\mathrm{NiO}$ powder synthesized by $\mathrm{NiCO}_{3} \cdot 2 \mathrm{Ni}(\mathrm{OH})_{2} \cdot 4 \mathrm{H}_{2} \mathrm{O}$ or $\mathrm{Ni}\left(\mathrm{NO}_{3}\right)_{2} \cdot 6 \mathrm{H}_{2} \mathrm{O}$ decomposition technique.
\end{abstract}

Key words: Solid oxide fuel cell, Ni-SDC anode, Electrical conductivity, Microstructure, NiO powder, Fabrication method doi:10.1631/jzus.2005.B1124 Document code: A CLC number: TM911.4; O614.33

\section{INTRODUCTION}

The solid oxide fuel cell (SOFC) has attracted much attention as a promising source of electrical power generation because of its high efficiency in converting chemical energy to electrical power. Development of SOFC with operating temperature of less than $800{ }^{\circ} \mathrm{C}$ has been extensively studied. SOFC has the potential to have the cost of its materials, cell fabrication, and corrosion of its stack components dramatically reduced. Gadolinia-doped ceria with the chemical formula $\mathrm{Ce}_{0.9} \mathrm{Gd}_{0.1} \mathrm{O}_{1.95}$ (GDC) is considered to be one of the most promising electrolytes for low temperature SOFC (Mogensen et al., 2000; Singhal, 2000; Steele, 2000), primarily due to its high ionic conductivity and negligible electrical conductivity

${ }^{\ddagger}$ Corresponding author under operating conditions (Xia and Liu, 2002).

The anode is an important part of the SOFC, as it provides the proper sites for electrochemical oxidation of the fuel and delivers the produced electrons to the interconnector (Lee et al., 2003). $\mathrm{Ni}-\mathrm{Ce}_{0.8} \mathrm{Sm}_{0.2} \mathrm{O}_{1.9}$ (Ni-SDC) is a kind of promising anode material for GDC electrolyte. Ni acts as a cheap catalyst, while SDC acts as a matrix to support the catalyst (Zha et al., 2004). The electrical conductivity is an important index of anode performance.

Although Ni-SDC composite cermets have been widely used as anode material, the effect of the fabrication condition of raw powders on anode performance has been rarely reported. Since the anode performance depends strongly on the fabrication method of $\mathrm{NiO}$ powder, it is necessary to do some research on it.

It was proved that the electrochemical activity of 
the cermet anode strongly depends on the three-phase boundary (TPB) composed of Ni grains, SDC grains and pores (de Boer et al., 2000). It increases with the increasing TPB length, because larger TPB provides larger reacting surface area (Fukui et al., 2004). Therefore, TPB length is a crucial factor in improving the anode performance. The original powder preparation technique can influence the TPB length.

In this study, SDC and four types of $\mathrm{NiO}$ powders were prepared for fabrication of four types of Ni-SDC anodes. The electrical conductivity of the anodes was measured, the effect of $\mathrm{NiO}$ powder preparation technique on $\mathrm{NiO}$ powder morphologies, microstructure of the cermet anode, particle sizes and electrical conductivity of anodes were investigated.

\section{EXPERIMENTAL PROCEDURE}

\section{SDC powder synthesis}

Stoichiometric amounts of $\mathrm{Ce}\left(\mathrm{NO}_{3}\right)_{3} \cdot 6 \mathrm{H}_{2} \mathrm{O}$, $\mathrm{Sm}_{2} \mathrm{O}_{3}\left(\mathrm{Sm}_{2} \mathrm{O}_{3}\right.$ was dissolved in $\left.\mathrm{HNO}_{3}\right)$ were mixed in distilled water, then $1.5 \mathrm{~mol}$ of citric acid was added to the mixture for each mol of metal ion and some ammonia was added to adjust $\mathrm{pH}$ value to 7 . The mixture was heated to cause evaporation of the solvent. After spontaneous ignition, the resulted foam-shape ash was collected and calcined in air at $600{ }^{\circ} \mathrm{C}$ for $2 \mathrm{~h}$ to remove carbon residue.

\section{Preparation of four kinds of $\mathrm{NiO}$ powder}

There are many different ways to prepare $\mathrm{NiO}$ powder. The four different $\mathrm{NiO}$ methods chosen are listed below:

1. Certain amount of $\mathrm{Ni}\left(\mathrm{NO}_{3}\right)_{2} \cdot 6 \mathrm{H}_{2} \mathrm{O}$ was dissolved in distilled water, then $1.5 \mathrm{~mol}$ of citric acid was added for each mol of metal ion and some ammonia was added to adjust $\mathrm{pH}$ value to 7 . The mixture was heated to cause evaporation of the solvent. After spontaneous ignition, the resulted foam-shape ash was collected and calcined in air at $850^{\circ} \mathrm{C}$ for $2 \mathrm{~h}$ to remove carbon residue.

2. $\mathrm{NiO}$ powder $(99.0 \%)$ was bought from the commercial market.

3. $\mathrm{NiCO}_{3} \cdot 2 \mathrm{Ni}(\mathrm{OH})_{2} \cdot 4 \mathrm{H}_{2} \mathrm{O}$ powder was placed in a muffle furnace in air at $650{ }^{\circ} \mathrm{C}$ for $2.5 \mathrm{~h}$, then cooled to room temperature.

4. $\mathrm{Ni}\left(\mathrm{NO}_{3}\right)_{2} \cdot 6 \mathrm{H}_{2} \mathrm{O}$ powder was placed in a muf- fle furnace and heated in air at $650{ }^{\circ} \mathrm{C}$ for $2.5 \mathrm{~h}$, then cooled to room temperature.

\section{Anode fabrication}

For all the anodes in this study, SDC powder was mixed with $\mathrm{NiO}$ powder at the mass rate of $1: 1$. This mixture with added binder was ball-milled for $24 \mathrm{~h}$ to form a homogenous powder that was cold pressed under $30 \mathrm{MPa}$ into wafers $(\Phi 25 \mathrm{~mm} \times 1 \mathrm{~mm})$. The shaped wafers were put into the muffle furnace to heat up at $1250^{\circ} \mathrm{C}$ for $5 \mathrm{~h}$, then reduced in hydrogen at 820 ${ }^{\circ} \mathrm{C}$ for $2.5 \mathrm{~h}$ to complete the anode fabrication.

\section{Measurement procedure}

The crystallization behavior of the synthesized powders was examined by X-ray powder diffraction (XRD, D-max-rA) using $\mathrm{Cu}-\mathrm{K} \alpha$ radiation. The microstructure and particle size were analyzed by Field Scanning Electron Microscopy (FSEM, SIRION). The pore property was investigated by automatic Mercury Porosimeter (Poremaster60, Quantachrome).

The electrical conductivity of the Ni-SDC cermets was measured between $100{ }^{\circ} \mathrm{C}$ and $800{ }^{\circ} \mathrm{C}$ by four probe DC method. Specimen was cut into the shape of bar using low-speed saw and connected with $\mathrm{Pt}$ wire and paste, then put into a reaction furnace using $\mathrm{H}_{2}$-Ar mixed gas $\left(\mathrm{H}_{2}: \mathrm{Ar}=2: 98,99.999 \%\right)$ as a carrier gas at fixed flow rate of $60 \mathrm{ml} / \mathrm{min}$. S-type thermocouple was used to measure the temperature of the sample and Keithley 2182 was used to input the temperature to a computer. The resistance was measured with Model LR-700 AC Resistance Bridge.

\section{RESULTS AND DISCUSSION}

\section{Powder characteristics}

Fig. 1 shows the X-ray diffraction patterns of the $\mathrm{SDC}$ and NiO powders used to produce the test anodes. NiO powders obtained from the above methods were named NiO-a, NiO-b, NiO-c and NiO-d, respectively. It can be seen that the SDC sample exhibits all peaks associated with that of a pure fluorite structure and that $\mathrm{NiO}$ samples have good cube crystal shape. The micrographs of the $\mathrm{NiO}$ and SDC powders are shown in Fig.2. NiO-a particle size averaged $300 \mathrm{~nm}$. It can also be seen that NiO-a forms agglomerates. Possibly because citric acid is a kind of 
chelating reagent inducing chelation of $\mathrm{Ni}\left(\mathrm{NO}_{3}\right)_{2} \cdot 6 \mathrm{H}_{2} \mathrm{O}$ and causes $\mathrm{NiO}$ powder to agglomerate. NiO-b and NiO-c have good dispersibility and uniform particle diameter. The average particle size of NiO-b is $200 \mathrm{~nm}$, while that of NiO-c is $100 \mathrm{~nm}$. $\mathrm{NiO}-\mathrm{d}$ obviously consists of two kinds of particle with size range of about $100 \mathrm{~nm}$ and $800 \mathrm{~nm}$ respectively. It is considered that there are two kinds of growing modes for NiO-d particles and that the process of developing smaller size particles is dominated by the experiment condition. The SDC powder has average particle size of $30 \mathrm{~nm}$. Table 1 shows the specific surface area of the SDC and $\mathrm{NiO}$ powders measured by nitrogen adsorption according to the Brunauer, Emmett and Teller (BET) method with QUANTACHROME AUTOSORB-1 instrument. SEM analysis showed that the specific surface area increases as the particle size decreases.

Table 1 The specific surface area of the $\mathrm{NiO}$ and SDC powder

\begin{tabular}{cccccc}
\hline & NiO-a & NiO-b & NiO-c & NiO-d & SDC \\
\hline Multipoint & 0.6735 & 2.404 & 4.348 & 3.675 & 15.75 \\
BET $\left(\mathrm{m}^{2} / \mathrm{g}\right)$ & & & & & \\
\hline
\end{tabular}

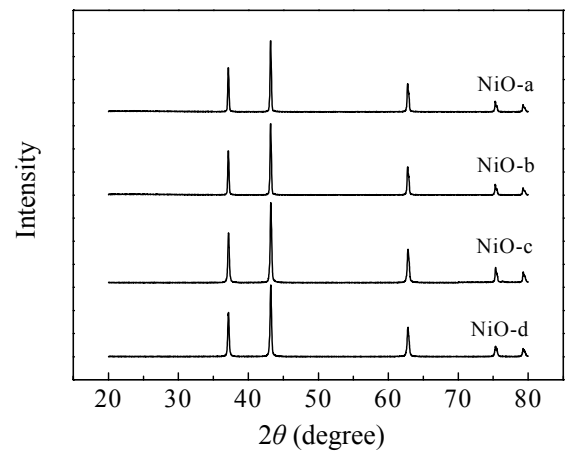

(a)

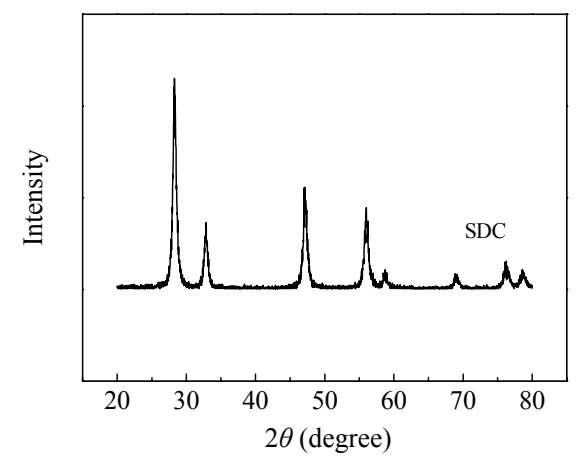

(b)

Fig.1 Power X-ray diffraction patterns for (a) $\mathrm{NiO}$ and (b) SDC

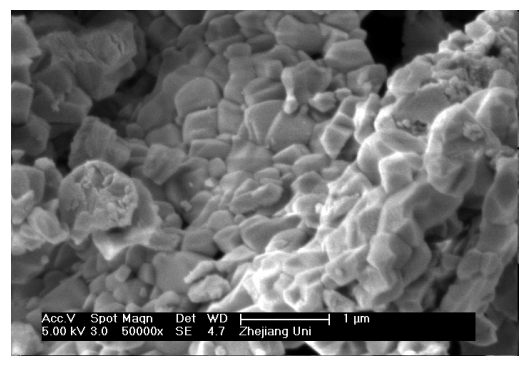

(a)

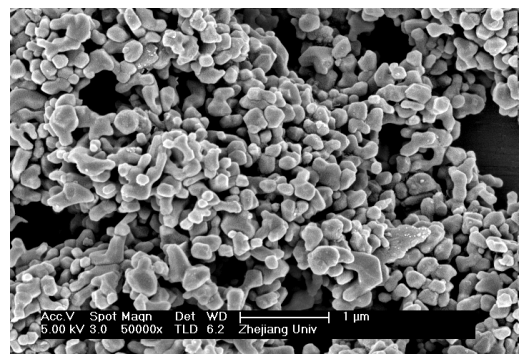

(b)

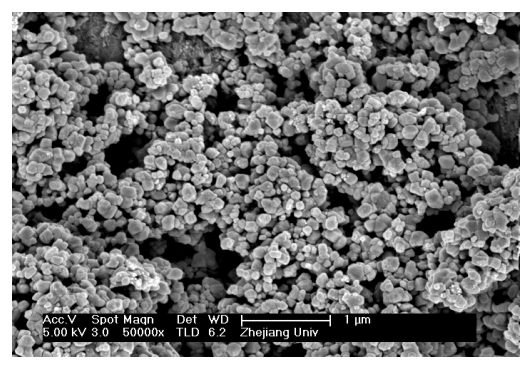

(c)

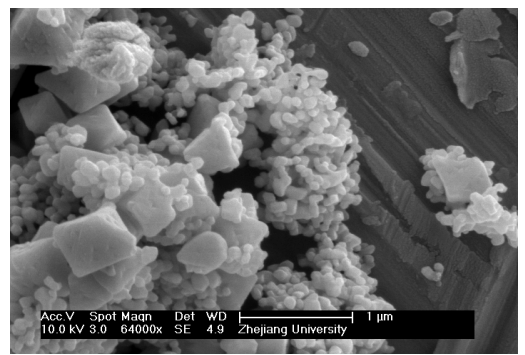

(d)

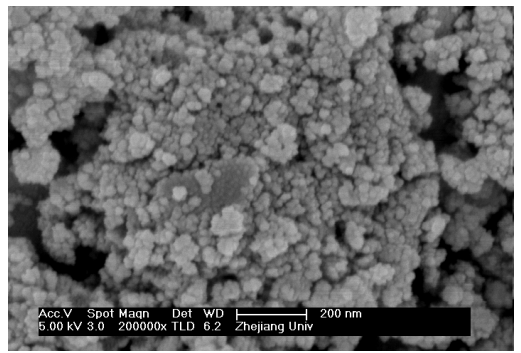

(e)

Fig.2 SEM photographs of the precursor powder used for anodes (a) NiO-a; (b) NiO-b; (c) NiO-c; (d) NiO-d; (e) SDC 


\section{Electrical conductivity with different anodes}

The anodes made of the above $\mathrm{NiO}$ powder were named anode-a, anode-b, anode-c and anode-d, respectively. The electrical conductivity of the four kinds of anodes as a function of temperature are given in Fig. 3 and Table 2. Fig. 3 shows that anode-c and anode-d have the highest electrical conductivity and show metal characteristic and that at all temperature ranges the electrical conductivity reduces with increasing temperature. Anode-b also shows metal characteristic at all temperature range, but with lower electrical conductivity than anode-c and anode-d. Anode-a shows metal characteristic at low temperature and nonmetal characteristic at high temperature when the electrical conductivity increases with increasing temperature. The reason is that NiO-a has agglomerates and cannot be well dispersed due to its agglomeration. Therefore SDC has considerable influence on the specimen electrical conductivity. In general, the anode-a has the lowest electrical conductivity.

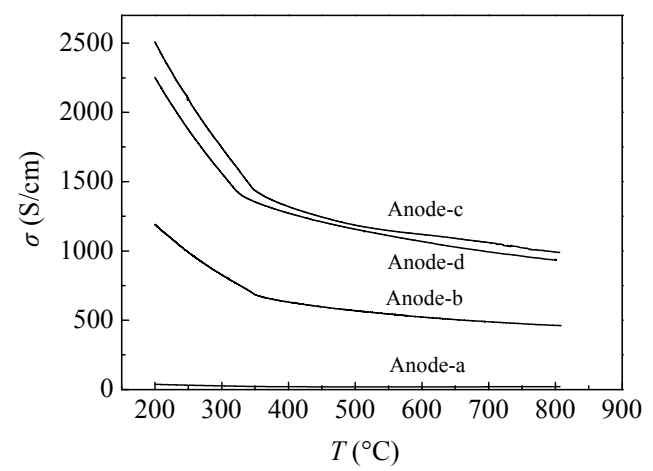

(a)

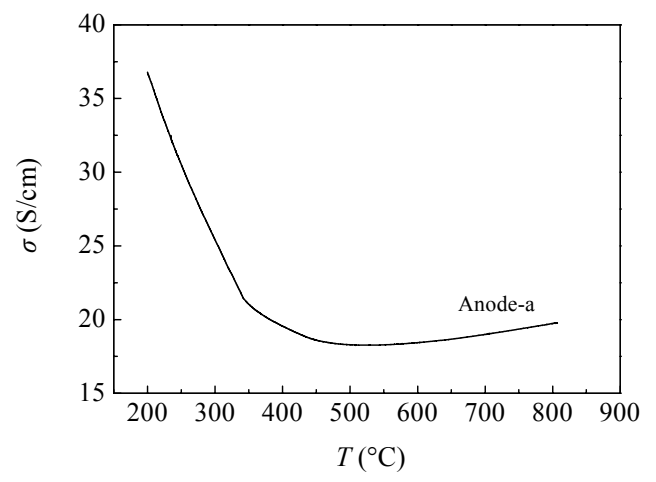

(b)

Fig.3 Electrical conductivity of four kinds of anodes (a) Anode-a, b, c, d; (b) Anode-a
Table 2 Electrical conductivity of different anodes at different temperature $(\mathrm{S} / \mathrm{cm})$

\begin{tabular}{lrrrrr}
\hline & $400{ }^{\circ} \mathrm{C}$ & $500{ }^{\circ} \mathrm{C}$ & $600{ }^{\circ} \mathrm{C}$ & $700{ }^{\circ} \mathrm{C}$ & $800{ }^{\circ} \mathrm{C}$ \\
\hline Anode-a & 19.55 & 18.29 & 18.44 & 18.99 & 19.72 \\
Anode-b & 630.58 & 568.48 & 523.37 & 489.15 & 462.77 \\
Anode-c & 1320.30 & 1186.37 & 1119.09 & 1059.70 & 991.97 \\
Anode-d & 1272.44 & 1157.06 & 1067.17 & 993.65 & 933.16 \\
\hline
\end{tabular}

Fig. 3 shows that the electrical conductivity of the anodes depends strongly on the fabrication condition of NiO. Anode-c and anode-d have similar fabrication condition of $\mathrm{NiO}$ powder and have the highest electrical conductivity. Anode-b having relatively bigger $\mathrm{NiO}$ particle size has lower electrical conductivity. NiO-a forms agglomerates during production because of the added citric acid, which results in the lowest electrical conductivity. It is obvious that the electrical conductivity is affected by the anode microstructure that in turn is influenced by the $\mathrm{NiO}$ powders fabrication condition.

\section{Anode microstructure}

The SEM photos of the four kinds of anode wafers are shown in Fig.4. Both NiO and SDC grains coarsen during firing. In anode-c and anode-d, the particles are uniformly distributed and connected and large numbers of nanometer size pores are uniformly dispersed, which is desirable for anodic reactions and electric conduction. Anode-c and anode-d have smaller average grain size and a more homogenous microstructure than anode-b due to the smaller particle size of $\mathrm{NiO}$ powder. As can be seen from Fig.4a, anode-a has a bigger average grain size and cannot form obvious network structure even after $24 \mathrm{~h}$ ball milling. In anode-a, the NiO-a prepared by citric acid-nitrate low temperature self-propagating combustion method tends to aggregate more easily, over wide range of $\mathrm{NiO}$ size, forming islands of isolated $\mathrm{NiO}$ grains. Accordingly, these $\mathrm{NiO}$ "islands" and larger pores result in poor Ni distribution.

The specific pore volume distribution $\left(D_{v}\right)$, pore specific surface area and mean pore diameter of the four kinds of anode wafers are shown in Fig.5 and given in Table 3. The specific pore volume of anode-a, $\mathrm{b}, \mathrm{c}, \mathrm{d}$ is distributed in the pore diameter range of $5 \sim 1500 \mathrm{~nm}, 0 \sim 550 \mathrm{~nm}, 0 \sim 500 \mathrm{~nm}$ and $8 \sim 500 \mathrm{~nm}$, respectively. It can be seen that specific pore volume, mean pore diameter and pore specific surface area 


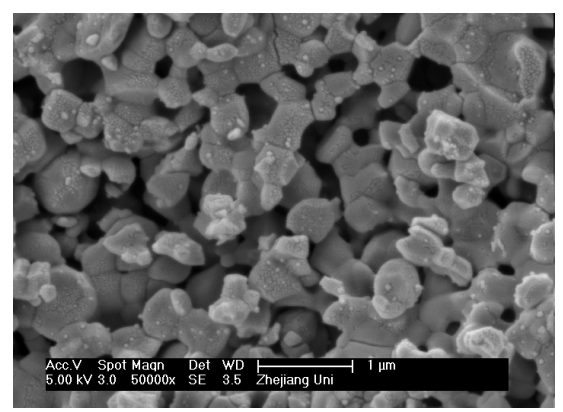

(a)

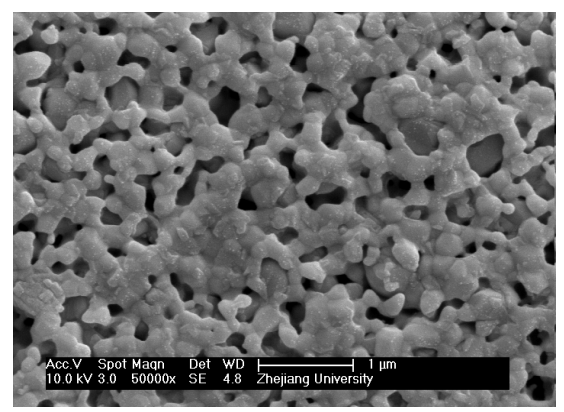

(c)

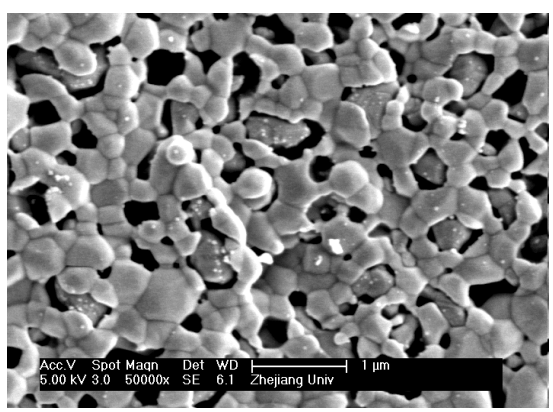

(b)

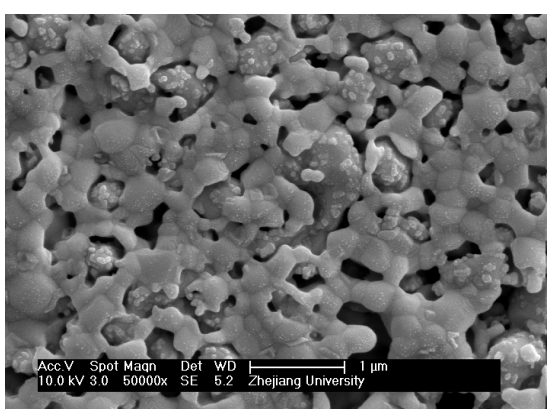

(d)

Fig.4 SEM photos for four kinds of anodes (a) Anode-a; (b) Anode-b; (c) Anode-c; (d) Anode-d

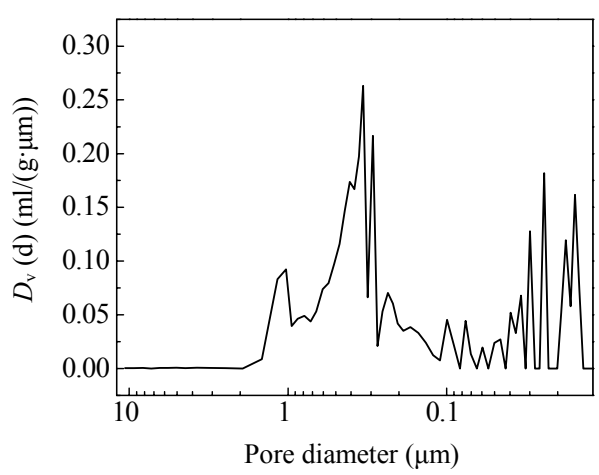

(a)

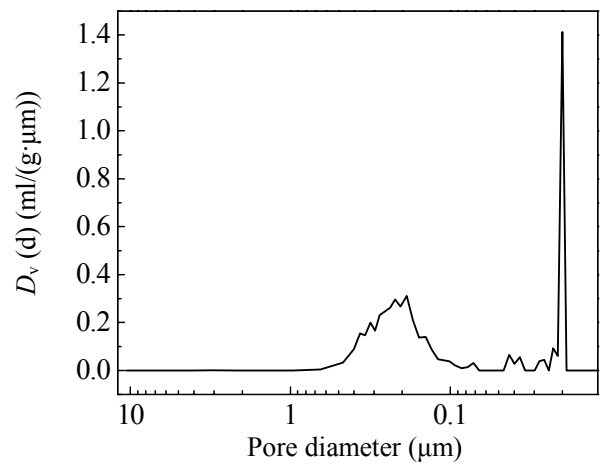

(c)

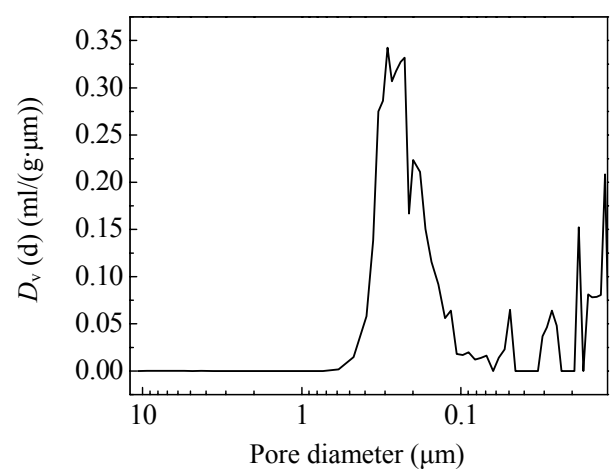

(b)

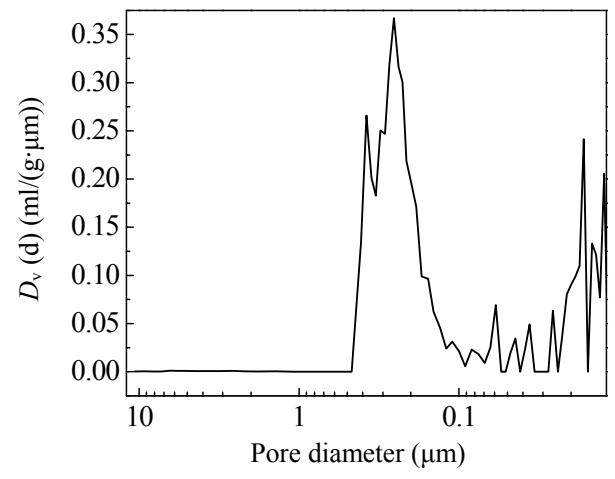

(d)

Fig.5 Pore diameter distribution of four kinds of anodes (a) Anode-a; (b) Anode-b; (c) Anode-c; (d) Anode-d 
Table 3 The pore property of the four kinds of Ni-SDC anodes

\begin{tabular}{ccccc}
\hline Sample name & Anode-a & Anode-b & Anode-c & Anode-d \\
\hline Specific surface area $\left(\mathrm{m}^{2} / \mathrm{g}\right)$ & 1.23 & 1.32 & 1.83 & 1.6 \\
Mean pore diameter $(\mathrm{nm})$ & 349.2 & 198.92 & 147.86 & 179.66 \\
\hline
\end{tabular}

analysis results are consistent with the result of SEM photos. The specific surface areas are in the order: anode-c $>$ anode- $d>$ anode- $b>$ anode- $a$. The mean pore diameters are in the order: anode- $a>$ anode- $b>a n-$ ode-d $>$ anode-c.

It is well known that long TPB, large surface area, uniform pore size and Ni distribution, and sufficient nickel content in the anode are essential for achieving high performance. For an Ni-SDC anode, the nickel grains are regarded as the active sites for $\mathrm{H}_{2}$ oxidation, while the SDC grains serve as mechanical support for nickel, so the distribution uniformity between Ni and SDC particles are of great importance. Although the four kinds of anodes have the same percentage of $\mathrm{Ni}$, the different $\mathrm{NiO}$ powders make them have different microstructure. The microstructures of anode-c and anode-d most satisfy all the requirements, which make them have the highest electrical conductivity. In contrast, the larger $\mathrm{Ni}$ grain in anode-b reduces TPB length, which results in lower electrical conductivity. The observed poor distribution between Ni and SDC in anode-a is responsible for the worst electrical conductivity performance.

\section{CONCLUSION}

SDC powder and four kinds of $\mathrm{NiO}$ powders were prepared, and four kinds of anodes were fabricated and investigated. The results showed that SDC can be well synthesized by citric acid-nitrate low temperature self-propagating combustion method. Different fabrication methods for $\mathrm{NiO}$ powder can result in different microstructures of anode. Electrical conductivity of an anode depends strongly on the microstructure of the cermet anode. $\mathrm{NiO}$ decomposed from $\mathrm{NiCO}_{3} \cdot 2 \mathrm{Ni}(\mathrm{OH})_{2} \cdot 4 \mathrm{H}_{2} \mathrm{O}$ or $\mathrm{Ni}\left(\mathrm{NO}_{3}\right)_{2} \cdot 6 \mathrm{H}_{2} \mathrm{O}$ has better dispersibility than $\mathrm{NiO}$ synthesized by citric acid-nitrate low temperature self-propagating combustion method. The anode including more dispersive and finer $\mathrm{NiO}$ powder has higher electrical conductivity. The electrical conductivity of the four kinds of anodes is $19.72 \mathrm{~S} / \mathrm{cm}, 462.77 \mathrm{~S} / \mathrm{cm}, 991.97 \mathrm{~S} / \mathrm{cm}$ and $933.16 \mathrm{~S} / \mathrm{cm}$ at $800{ }^{\circ} \mathrm{C}$, respectively.

\section{References}

de Boer, B., Gonzalez, M., Bouwmeester, H.J.M., Verweij, H., 2000. The effect of the presence of fine YSZ particles on the performance of porous nickel electrodes. Solid State Ionics, 127:269-276.

Fukui, T., Murata, K., Ohara, S., Abe, H., Naito, M., Nogi, K., 2004. Morphology control of Ni-YSZ cermet anode for lower temperature operation of SOFCs. Journal of Power Sources, 125:17-21.

Lee, J.H., Heo, J.W., Lee, D.S., Kim, J., Kim, G.H., Lee, H.W., Song, H.S., Moon, J.H., 2003. The impact of anode microstructure on the power generating characteristics of SOFC. Solid State Ionics, 158:225-232.

Mogensen, M., Sammes, N.M., Tompett, G.A., 2000. Physical, chemical and electrochemical properties of pure and doped ceria. Solid State Ionics, 129:63-94.

Singhal, S.C., 2000. Advances in solid oxide fuel cell technology. Solid State Ionics, 135:305-313.

Steele, B.C.H., 2000. Appraisal of $\mathrm{Ce}_{1-y} \mathrm{Gd}_{y} \mathrm{O}_{2-y / 2}$ electrolytes for IT-SOFC operation at $500{ }^{\circ} \mathrm{C}$. Solid State Ionics, 129:95-110.

Xia, C., Liu, M., 2002. Microstructures, conductivities, and electrochemical properties of $\mathrm{Ce}_{0.9} \mathrm{Gd}_{0.1} \mathrm{O}_{2}$ and GDC-Ni anodes for low-temperature SOFCs. Solid State Ionics, 152-153:423-430.

Zha, S.W., Rauch, W., Liu, M.L., 2004. Ni-Ce ${ }_{0.9} \mathrm{Gd}_{0.1} \mathrm{O}_{1.95}$ anode for GDC electrolyte-based low-temperature SOFCs. Solid State Ionics, 166:241-250. 